\title{
Gene expression of NMDA receptor subunits in the cerebellum of elderly patients with schizophrenia
}

\author{
Andrea Schmitt · Jiri Koschel · Mathias Zink · Manfred Bauer · Clemens Sommer • \\ Josef Frank · Jens Treutlein - Thomas Schulze · Thomas Schneider-Axmann · \\ Eleni Parlapani $\cdot$ Marcella Rietschel $\cdot$ Peter Falkai · Fritz A. Henn
}

Received: 8 October 2008/Accepted: 22 April 2009/Published online: 12 May 2009

(c) The Author(s) 2009. This article is published with open access at Springerlink.com

\begin{abstract}
To determine if NMDA receptor alterations are present in the cerebellum in schizophrenia, we measured NMDA receptor binding and gene expression of the NMDA receptor subunits in a post-mortem study of elderly patients with schizophrenia and non-affected subjects. Furthermore, we assessed influence of genetic variation in the candidate gene neuregulin-1 (NRG1) on the expression of the NMDA receptor in an exploratory study. Post-mortem samples from the cerebellar cortex of ten schizophrenic patients were compared with nine normal subjects. We investigated NMDA receptor binding by receptor autoradiography and gene expression of the NMDA receptor subunits NR1, NR2A, NR2B, NR2C and NR2D by in situ hybridization. For the genetic study, we genotyped the NRG1 polymorphism rs35753505 (SNP8NRG221533). Additionally, we
\end{abstract}

A. Schmitt $(\bowtie) \cdot$ T. Schneider-Axmann · E. Parlapani ·

P. Falkai

Department of Psychiatry, University of Goettingen,

von-Siebold Str. 5, 37075 Göttingen, Germany

e-mail: aschmit@gwdg.de

A. Schmitt - J. Koschel - M. Zink - J. Frank - J. Treutlein ·

T. Schulze - M. Rietschel - F. A. Henn

Central Institute of Mental Health, P.O. Box 122120,

68072 Mannheim, Germany

M. Bauer

Department of Neuropathology, University of Leipzig,

Liebigstr. 26, 04103 Leipzig, Germany

C. Sommer

Department of Neuropathology, University of Mainz,

Mainz, Germany

Present Address:

F. A. Henn

Life Sciences, Brookhaven National Laboratory,

Bldg. 490, Upton, NY 11973-5000, USA treated rats with the antipsychotics haloperidol or clozapine and assessed cerebellar NMDA receptor binding and gene expression of subunits to examine the effects of antipsychotic treatment. Gene expression of the NR2D subunit was increased in the right cerebellum of schizophrenic patients compared to controls. Individuals carrying at least one $\mathrm{C}$ allele of rs35753505 (SNP8NRG221533) showed decreased expression of the NR2C subunit in the right cerebellum, compared to individuals homozygous for the $\mathrm{T}$ allele. Correlation with medication parameters and the animal model revealed no treatment effects. In conclusion, increased NR2D expression results in a hyperexcitable NMDA receptor suggesting an adaptive effect due to receptor hypofunction. The decreased NR2C expression in $N R G 1$ risk variant may cause a deficit in NMDA receptor function. This supports the hypothesis of an abnormal glutamatergic neurotransmission in the right cerebellum in the pathophysiology of schizophrenia.

Keywords NMDA receptor subunits - Gene expression NMDA receptor binding - Cerebellum - Schizophrenia . Antipsychotics · Neuregulin-1

\section{Introduction}

The cerebellum is known to be involved in motor control, but positron emission tomography (PET) and functional magnetic resonance imaging (fMRI) studies have also shown the involvement of the cerebellum in different cognitive tasks $[2,51]$. During the last decades, the cerebellum has been implicated in the pathophysiology of schizophrenia, with the cortico-thalamo-cerebellar circuit receiving particular attention [4]. Evidence from PET as well as structural and functional MRI studies has shown 
decreased volumes of the total cerebellum, left cerebellar hemisphere and right vermis [60] as well as correlation of the volume reduction with psychopathological subscores $[26,43]$. This has raised questions concerning the underlying biological dysfunction. ${ }^{1} \mathrm{H}$-spectroscopic MRI studies have revealed decreased $N$-acetylaspartate (NAA) and creatine in the anterior vermis and cortex, pointing to altered neuronal integrity $[12,17]$. Reductions of NAA indicate a loss of functional and structural integrity of neurons, dendrites and axons. Such neuronal dysfunctions may involve a glutamatergic deficit in cerebellar subregions of schizophrenic patients.

The glutamate hypothesis of schizophrenia is based on the observation that phencyclidine and ketamine, which block the ion channel of the glutamatergic $N$-methyl-Daspartate (NMDA) receptor, initiate an NMDA receptor hypofunction and precipitate psychosis [29,30], resulting in a final hypoglutamatergic state of corticostriatal projections [18, 44]. The NMDA receptor is composed of different subunits, responsible for various functional properties [27, 39]. The obligate NR1 subunit combines two or three NR2 subunits (NR2A, NR2B, NR2C and NR2D) to form the functional receptor.

Studies, using brain tissue obtained from post-mortem, have examined the expression of glutamate receptor subunits and support the hypothesis of a glutamate dysfunction in schizophrenia. In contrast to neocortical brain regions, molecular investigations of the cerebellum are sparse concerning schizophrenia. In cerebellar Purkinje and Golgi neurons, all NMDA receptor subunits are expressed [10, 52] and may be altered in schizophrenia. However, one study investigating only the left cerebellar granule cell layer showed no difference in gene expression of NMDA receptor subunits compared to healthy controls [1]. The expression of the NR2C subunit has been reported to be regulated by neuregulin-1 in maturing synapses of the cerebellar granule cells [47]. Several studies suggest $N R G 1$ as a vulnerability gene for schizophrenia [23]. The mechanisms that might underlie the contribution of $N R G 1$ risk haplotypes to disease pathophysiology, however, remain elusive. Particularly, the influence of NRGl risk variants on the expression of subunits of the NMDA receptor is unknown.

The present study sought to determine whether the expression of genes encoding for NR1, NR2A, NR2B, NR2C and NR2D subunits of the NMDA receptor or NMDA receptor binding are specifically altered in the cerebellum. For additional investigation of a possible influence of $N R G 1$ genotype variation on the expression of the NR2C subunit, we genotyped the samples for the NRG1 polymorphism rs35753505 (SNP8NRG221533). This variant forms part of the previously reported risk haplotype for schizophrenia, and has been described as a tagging SNP of the core at-risk haplotype [23]. As all schizophrenic patients in our study had been on antipsychotic medication over long periods of time, medication effects have to be included as a possible influential factor. Accordingly, we conducted an additional animal study closely investigating the effects of a typical (haloperidol) and an atypical (clozapine) antipsychotic medication on NMDA receptor binding and gene expression of subunits of the NMDA receptor in different cerebellar rat brain regions after drug administration for up to 6 months.

\section{Method}

Human post-mortem tissue

Frozen post-mortem brain samples from inpatients with DSM-IV residual schizophrenia $(n=10)$ and elderly comparison subjects $(n=9)$ were collected at the Central Institute of Mental Health, Mannheim and the Department of Neuropathology, Wiesloch, Germany. The sex distribution, mean age, age at onset, duration of the disease, duration of hospitalization, last dose and cumulative dose during the last 10 years of antipsychotic medication in chlorpromazine equivalents (CPE), post-mortem interval (PMI), brain $\mathrm{pH}$ and storage time interval are shown in Table 1. Complete medical charts were available for all patients.

All schizophrenic patients had been long-term inpatients at the State Mental Hospital in Wiesloch, Germany. Patients were diagnosed ante mortem by an experienced psychiatrist, who also conducted diagnostic reviews of all medical charts. For each patient the history of antipsychotic treatment was assessed by examining the medical charts. Subject's last dose as well as the cumulative dose during the last 10 years of antipsychotic medication was calculated in chlorpromazine equivalents (CPE) through the algorithm developed by Jahn and Mussgay [28]. Autopsy consent was obtained from the donor or a family member in all cases. The Ethics Committee of the Faculty of Medicine of Heidelberg University, Germany, approved all assessments and post-mortem evaluations and procedures.

All patients and controls had undergone thorough neuropathologic characterization to rule out associated neurovascular or neurodegenerative disorders such as Alzheimer's disease and multi-infarct dementia [7, 8]. The staging according to Braak was 2 or less for all subjects. Patients and normal comparison subjects had no history of alcohol or drug abuse, or severe physical illness (like carcinoma). Normal comparison subjects had no history of psychiatric disorders. All patients had been receiving longterm antipsychotic medication before dying such as 
Table 1 Characteristics of post-mortem brain tissue from patients with schizophrenia and normal comparison subjects

\begin{tabular}{|c|c|c|c|c|}
\hline \multirow[t]{2}{*}{ Characteristic } & \multicolumn{2}{|c|}{$\begin{array}{l}\text { Tissue from } \\
\text { patients with } \\
\text { schizophrenia } \\
(n=10)\end{array}$} & \multicolumn{2}{|c|}{$\begin{array}{l}\text { Tissue from } \\
\text { normal } \\
\text { comparison } \\
\text { subjects } \\
(n=9)\end{array}$} \\
\hline & Mean & SD & Mean & SD \\
\hline \multicolumn{5}{|l|}{ Subject's gender $(N)$} \\
\hline Male & \multicolumn{2}{|l|}{4} & \multicolumn{2}{|l|}{3} \\
\hline Female & \multicolumn{2}{|l|}{6} & \multicolumn{2}{|l|}{6} \\
\hline \multicolumn{5}{|l|}{ Neuregulin-1 genotype $(N)$} \\
\hline $\mathrm{TT}$ & \multicolumn{2}{|l|}{4} & \multicolumn{2}{|l|}{4} \\
\hline $\mathrm{CT} / \mathrm{CC}$ & \multicolumn{2}{|l|}{6} & \multicolumn{2}{|c|}{$\begin{array}{l}4 \text { (1 not } \\
\text { determined) }\end{array}$} \\
\hline Age at death (years) & 63.70 & 12.21 & 64.56 & 14.51 \\
\hline Post-mortem interval (h) & 17.10 & 8.77 & 27.33 & 26.74 \\
\hline $\mathrm{pH}$ & 6.55 & 0.33 & 6.63 & 0.37 \\
\hline Storage time interval (months) & 27.82 & 10.76 & 24.59 & 8.29 \\
\hline Age at onset (years) & 24.60 & 7.36 & & \\
\hline Duration of the disease (years) & 39.10 & 11.77 & & \\
\hline Duration of hospitalization (years) & 25.10 & 15.32 & & \\
\hline $\begin{array}{l}\text { Duration of antipsychotic } \\
\text { medication } \\
\text { (years) }\end{array}$ & 35.00 & 9.72 & & \\
\hline $\begin{array}{l}\text { Last dose of antipsychotic } \\
\text { medication } \\
\text { in chlorpromazine equivalents } \\
\text { (CPE in gram) }\end{array}$ & 436.90 & 452.10 & & \\
\hline $\begin{array}{l}\text { Cumulative dose (last ten years) } \\
\text { of antipsychotic medication in } \\
\text { chlorpromazine equivalents } \\
\text { (CPE in kilogram) }\end{array}$ & 3.59 & 3.04 & & \\
\hline
\end{tabular}

clozapine $(n=3)$, zotepine $(n=1)$, olanzapine $(n=2)$, flupenthixole $(n=1)$, haloperidol $(n=3)$, perphenazine $(n=1)$, pipamperone $(n=1)$, promethazine $(n=1)$, tiapride $(n=1)$ and zuclopenthixol $(n=2)$.

The cerebellum was dissected in the midline of the vermis. Tissue blocks were prepared from cerebellar subregions, the anterior lateral hemisphere and anterior vermis from both hemispheres of the cerebellum. Blocks were immediately snap-frozen in liquid nitrogen-cooled isopentane, and stored at $-80^{\circ} \mathrm{C}$.

NRG1 rs35753505 (SNP8NRG221533), genotyping and use of online bioinformatics tools

Sequence information for NRG1 was obtained from the homepage of deCODE Genetics (http://decode.com/nrg1/ markers/SNPS.htm). SNP rs35753505 (SNP8NRG221533) was genotyped using Applied Biosystems 7900HT Fast Real-Time PCR System and TaqMan-probes designed by
Applied Biosystems (Foster City, California). Primers and VIC/FAM-probe sequences for rs35753505 (SNP8NR G221533) detection were: forward-5'-TTTAAGGCATCA GTTTTCAATAGCTTTTTTATGT-3'; Reverse-5'-AGAC AGATGTCTCAAGAGACTGGAA-3'; 5'-VIC-CATGTA TCTTTATTTTGCCAAAT- $3^{\prime} ; 5^{\prime}$-FAM-CATGTATCTTT ATTTTACCAAAT.

To test for functional constraint on the genomic region, in which rs35753505 (SNP8NRG221533) is located, crossspecies conservation analysis was carried out using the ECR browser (http://ecrbrowser.dcode.org). The ECR browser lists human SNPs which are located in evolutionary conserved regions (ECRs). ECRs are DNA regions that have been mapped to align with other genomes and are conserved with greater than or equal to $70 \%$ identity over at least 100 bp [38, 45]. For ECR browser analysis, genome assemblies hg18 (human), mm8 (mouse) and rn4 (rat) were used (ECR browser, February 2007).

Animal model of antipsychotic treatment

Animal use procedures were in strict accordance with the NIH guide for the Care and Use of Laboratory Animals and had been approved by the local animal ethical care committee. Male Sprague-Dawley rats (initial weight 250$280 \mathrm{~g}$, Janvier, France) were group housed 3 per cage under a 12-h light-dark cycle and fed ad libitum. Over a period of 6 months, 11 rats received either haloperidol (Janssen) at $1.5 \mathrm{mg} / \mathrm{kg} /$ day diluted in minimal acetic acid, clozapine (Novartis) at $45 \mathrm{mg} / \mathrm{kg} /$ day diluted in minimal $\mathrm{HCl}$ in the drinking water adjusted to $\mathrm{pH}$ 6.5. Control rats were given minimal $\mathrm{HCl}$ in the drinking water to match the $\mathrm{pH}$ levels of the drug solutions as described before [54, 64]. After 6 months of continuous drug administration, rats were killed by $\mathrm{CO}_{2}$. All brains were removed and frozen in liquid isopentane before being stored at $-80^{\circ} \mathrm{C}$ for approximately 4 months.

Human and animal brain processing

Adjacent coronal cryostat sections of rat and human brain tissues were processed at $-20^{\circ} \mathrm{C}$ and were thaw-mounted on superfrost plus microscopic slides, dried and stored as described earlier [54, 64]. Grey matter of the human cerebellar regions was delineated into the molecular and granular layer [21]. For NMDA receptor binding we did not investigate the molecular and granular layer separately due to lacking optical delineation of the two layers on tritium-sensitive films. Rat cerebellum regions were delineated into the left and right anterior hemispheres, total anterior vermis and a region containing all cerebellar nuclei according to the rat brain atlas of Paxinos and Watson [48]. 
Table 2 Primer fragments used in in situ-hybridization assessing gene expression of $N$ methyl-D-aspartic acid (NMDA) receptor (NR) subunits in postmortem brain specimens from human subjects and rats

\begin{tabular}{llll}
\hline Gene & $\begin{array}{l}\text { GenBank Accession } \\
\text { number }\end{array}$ & Fragment-position & $\begin{array}{l}\text { Fragment-size } \\
\text { (base-pairs) }\end{array}$ \\
\hline Rat NR1-3a & U_08266.1 & $2,472-2,996$ & 525 \\
Rat NR2A & M_91561.1 & $4,035-4,585$ & 551 \\
Rat NR2B & NM_008171 & $4,030-4,444$ & 415 \\
Rat NR2C & NM_012575.2 & $1,876-2,420$ & 544 \\
Rat NR2D & NM_022797.1 & $2,896-3,413$ & 518 \\
Human NR1 & NM_000832 & $2,134-2,835$ & 701 \\
Human NR2A & NM_000833 & $3,759-4,268$ & 509 \\
Human NR 2B & XM_006636 & $4,183-4,604$ & 415 \\
Human NR 2C & NM_000835 & $2,494-2,783$ & 290 \\
Human NR 2D & U_000836 & $2,042-2,546$ & 504 \\
\hline
\end{tabular}

NMDA receptor autoradiography in human and animal brain tissue

Using quantitative in vitro receptor autoradiography, binding to $N$-methyl-D-aspartate (NMDA) receptor was performed utilizing specific ligands according to the method by Zilles et al. [63]. Binding assays were performed in the presence of $30 \mu \mathrm{M}$ glycine and $50 \mu \mathrm{M}$ spermidine with $5 \mathrm{nM}\left[{ }^{3} \mathrm{H}\right]-\mathrm{MK}-801$ (dizocilpine maleate) at $22^{\circ} \mathrm{C}$ for $60 \mathrm{~min}$. In adjacent sections, non-specific binding was determined by adding MK-801 in 20,000-fold excess $\left[10^{-4} \mathrm{~m}(+)\right.$ MK-801] into the incubation solution. Non-specific binding was subtracted from total binding to obtain specific binding.

$\left[{ }^{3} \mathrm{H}\right]$-sensitive film (Hyperfilm, Amersham) was exposed to Tritium-labelled sections for 4 weeks. Autoradiograms were digitized using an image analysis system (Inter Active Systems, Interfocus Germany). The grey value images of the co-exposed plastic $\mathrm{C}^{14}$ standards were used to compute a calibration curve by non-linear, least-squares fitting, which defined the relationship between grey values and concentration of radioactivity. The plastic standards were calibrated to tissue standards prepared from homogenized brain tissue with known protein content in order to express binding site densities on $\mathrm{fmol} / \mathrm{mg}$ protein as described earlier [54, 64].

In situ hybridization

The expression of NMDA receptor subunits was evaluated by semiquantitative in situ-hybridization using specific human and rat probes as listed in Table 2. Using subcloned cDNA fragments as templates, we produced radioactively labelled cRNA probes by in vitro transcription as described earlier [38, 54]. Hybridization with antisense probes $\left(10^{7} \mathrm{cpm} / \mathrm{ml}\right)$ was carried out at $55^{\circ} \mathrm{C}$ under high stringency conditions [50\% formamide (Sigma)] and specificity was verified by the inclusion of sense probes. After RNAse
A digest and dehydration, X-ray films (Biomax MR1) were exposed to slices for 2-6 days. Results were quantified using the analysis image system (see also NMDA receptor binding).

Materials and medication

$\left[{ }^{3} \mathrm{H}\right]-\mathrm{MK}-801$ was obtained from NEN (Life Science Products, Germany). Unlabelled MK-801 was purchased from Sigma (Taufkirchen, Germany). Haloperidol (Janssen Research Foundation) and clozapine (Novartis, Basel, Switzerland) were provided by the respective companies. All other chemicals were purchased from Sigma Chemicals (Taufkirchen, Germany).

Statistical analysis

Statistical analyses were performed with SPSS11 [42]. All tests were two-tailed. The level of significance was defined as $P<0.05$. Results are presented as mean \pm standard deviation.

Post-mortem human data

Distributions for all dependent variables were examined in the two groups using histograms and the KolmogorovSmirnov test on normality [35]. Though the power for the Kolmogorov-Smirnov test was not very high due to the small sample size, the results nevertheless suggest a normal distribution of the data and analysis by parametric tests. Stepwise linear regression analyses $\left(P_{\text {in }}=0.05, P_{\text {out }}=\right.$ 0.10 ) with the independent variables gender, age and PMI were performed for all dependent variables. Analyses of covariance (ANCOVA) were conducted to test for diagnostic group differences. The intervening factor gender and covariates age, PMI, storage time and brain $\mathrm{pH}$ were added to our analyses, if they showed significant influence in the initial regression analysis. Since NMDA receptor subunits 
were measured independently with different probes in different experiments, differences between diagnostic groups were assessed with independent tests for significance. For additional investigation of the influence of $N R G 1$ genotype on the expression of the NR2C subunit, ANOVA with factor NRGl genotype (CT/CC vs. TT) was calculated. Correlations between variables were performed using Pearson product moment correlation coefficients.

Data from animal model

The Kolmogorov-Smirnov test on normality was applied. Since there were significant deviations from the normal distribution assumption, comparisons between the three groups were analysed by Kruskal-Wallis tests and subsequently by two-tailed Wilcoxon Mann Whitney $U$ tests.

\section{Results}

Gene expression of NMDA receptor subunits in the left and right anterior hemisphere, vermis, granular and molecular layers of the cerebellum for schizophrenic patients and healthy controls is shown in Fig. 1. Expression of the NR2D subunit in all right-side cerebellar regions was significantly higher in the schizophrenia group compared with our group of normal elderly controls (vermis: molecular layer $F=13.26 ; d f=1,14 ; P=0.003$, granular layer $F=6.43$; $d f=1,14 ; P=0.024$; hemisphere: molecular layer $F=6.13 ; d f=1,17 ; P=0.024$, granular layer $F=4.92$; $d f=1,17 ; P=0.04)$. We found no difference in the left hemisphere and vermis. NR1, NR2A, NR2B and NR2C subunits did not differ significantly. Additionally, NMDA receptor binding revealed no difference in any cerebellar region between schizophrenic patients and healthy controls. In both schizophrenic patients and normal comparison subjects the NRG1 rs35753505 (SNP8NRG221533) schizophrenia-risk genotypes containing at least one $\mathrm{C}$ allele (CC and CT) decreased gene expression of the NR2C subunit in the molecular layer of the right vermis $(F=5.2$; $d f=1,15 ; P=0.037)$ and hemisphere $(F=4.9 ; d f=1$, $16 ; P=0.041$ ) compared to the TT genotype (Fig. 2). In the left side, we found no genotype-specific differences.

SNP rs35753505 (SNP8NRG221533) is localized upstream of all transcript isoforms (RefSeq) of neuregulin 1, as shown in Fig. 3. ECR browser analysis (ECR browser, Feb. 2007) revealed that rs35753505 (SNP8NRG221533) is listed among human SNPs which are located in ECRs (greater than or equal to $70 \%$ identity over at least $100 \mathrm{bp}$, human-mouse comparison). ECR browser 'Grab ECR' alignment from both species in pairwise comparisons (Fig. 4a, b) showed the base position of rs35753505 (SNP8NRG221533) localized in a long conserved homologous stretch (human/mouse, 400 bps, $74.8 \%$ identity, hg18 chr8:31593526-31593925; human/rat, 295 bps, 73.6\% identity, hg18 chr8:31593526-31593820), which suggests selection on the genomic region harbouring the polymorphism. The location of the ECR relative to rs35753505 (SNP8NRG221533) and neuregulin 1 transcript isoforms (RefSeq) is shown in Fig. 3.

Patients did not differ regarding age $(F=0.0 ; d f=1$, $17 ; P=0.89)$, PMI $(F=1.3 ; d f=1,17 ; P=0.27)$ and gender $\left(\chi^{2}=0.1 ; d f=1 ; P=0.76\right)$ compared to the normal elder group (Table 1). Regression analysis revealed a significant influence of gender (increased in males vs. females, $F=6.2 ; d f=1,16 ; P=0.025)$ and age $(r=-0.57 ; d f=15 ; P=0.018)$ on the expression of NR2D subunit in the molecular layer of the left hemisphere or vermis, respectively. In the left granular layer, age had an influence on NR2A subunit $(r=0.46$; $d f=17 ; P=0.048)$ in the hemisphere and PMI on the expression of NR1 subunits $(r=-0.49 ; \quad d f=16$; $P=0.039)$ in the vermis. Therefore, these variables were entered to the main analyses as covariates. Duration of illness correlated positively with gene expression of the NR2C subunit in the molecular layer of the right hemisphere $(r=0.70 ; d f=8 ; P=0.02)$ and right vermis $(r=0.71 ; d f=7 ; P=0.03)$ as well as bilaterally in the granular layer of the hemispheres (right: $r=0.69, d f=8$, $P=0.03$; left: $r=0.65, d f=8, P=0.04)$ and vermis (right: $r=0.77, d f=7, P=0.02$; left: $r=0.75, d f=7$, $P=0.02$ ). Additionally, duration of illness correlated negatively with gene expression of the NR2D subunit in the molecular layer $(r=-0.71 ; d f=7 ; P=0.03)$ and in the granular layer $(r=-0.78 ; d f=7 ; P=0.01)$ of the left vermis.

All schizophrenic patients had been exposed to antipsychotic medication for decades (Table 1). Furthermore, patients had been receiving antipsychotic medication to within 1 week of death. Duration of medication correlated with expression of the NR2C subunit in the molecular layer of the right hemisphere $(r=0.66 ; d f=8 ; P=0.04)$ and vermis $(r=0.69 ; d f=7 ; P=0.04)$. In the molecular layer of the left vermis, duration of medication correlated negatively with expression of the NR2D subunit $(r=$ $-0.73 ; d f=7 ; P=0.03)$. In the granular layer of the vermis, duration of medication correlated with expression of the NR2C subunit (right: $r=0.82, d f=7, P=0.01$; left: $r=0.75, d f=7, P=0.03$ ) and negatively with expression of the NR2D subunit (left: $r=-0.79 ; d f=7$; $P=0.01)$. There was no correlation between gene expression of NMDA receptor subunits and last dose or cumulative dose in CPE.

In the animal model of long-term antipsychotic treatment, Kruskal-Wallis test revealed a significant group effect of NR2C gene expression $\left(\chi^{2}=7.0 ; \quad d f=2\right.$; 

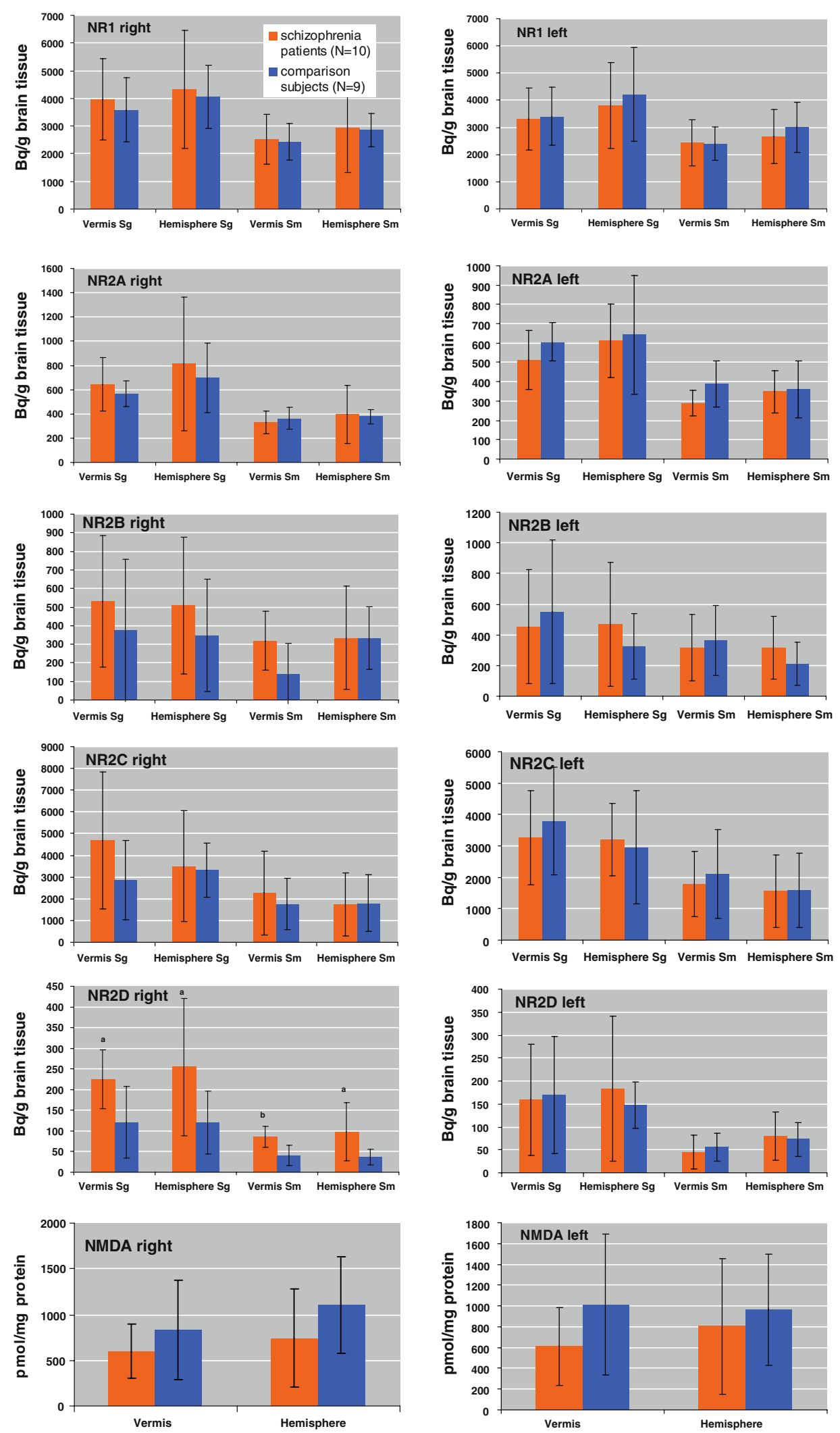

Fig. 1 Gene expression of $N$-methyl-D-aspartate (NMDA) receptor subunits NR1, NR2A, NR2B, NR2C and NR2D expressed as Bq/g brain tissue in the molecular layer (stratum moleculare: $\mathrm{Sm}$ ) and granular layer (stratum granulare: $S g$ ) of the right and left vermis and

hemispheres. NMDA receptor binding expressed as $\mathrm{pmol} / \mathrm{mg}$ protein in the right and left vermis and hemispheres. ${ }^{\text {a,b }}$ Significantly different from comparison group ${ }^{\mathrm{a}} P<0.05,{ }^{\mathrm{b}} P<0.01$ ) 


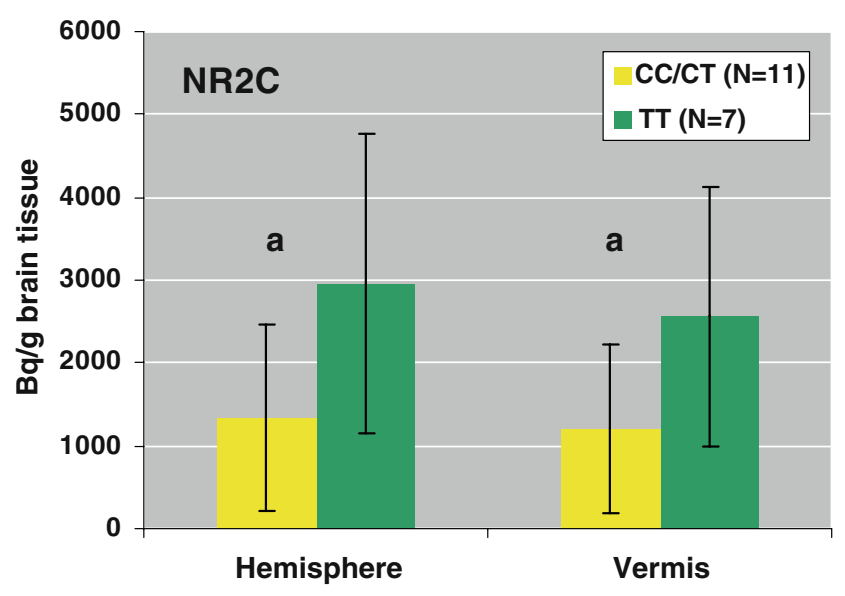

Fig. 2 Gene expression of the NR2C subunit in the risk genotype containing at least one $\mathrm{C}$ allele (CC/CT) compared to the TT allele in the cerebellar molecular layer of the right hemisphere and vermis in patients with schizophrenia and normal comparison subjects expressed as $\mathrm{Bq} / \mathrm{g}$ brain tissue. ${ }^{\mathrm{a}}$ Significantly different from comparison group ${ }^{\mathrm{a}} \mathrm{P}<0.05$

$P=0.030)$. As shown by a subsequent Mann-Whitney $U$ test expression of $\mathrm{NR} 2 \mathrm{C}$ was increased in clozapine treated animals compared to haloperidol treatment $(Z=-2.5$; $d f=1 ; P=0.038$ ). There was no significant difference in the gene expression of NR1, NR2A, NR2B, NR2C and NR2D subunits or NMDA receptor binding between salinetreated rats and groups receiving clozapine or haloperidol treatment.

\section{Discussion}

The present post-mortem studies revealed overexpression of the NR2D subunit of the NMDA receptor in the molecular and granular layer of the right cerebellar hemisphere and vermis of elderly schizophrenic patients hospitalized for the long term. These results point in the same direction as increased expression of NR2D subunit in the left prefrontal cortex [1]. Subtle shifts in composition of NMDA receptors may have considerable effects on receptor function. In contrast to receptors containing a combination of NR1 with NR2A or NR2B subunits, NMDA receptors assembled from NR1 and NR2D subunits show a prolonged decay rate of glutamate-induced ion currents and lowered threshold for voltage-dependent magnesium blockade. This causes a 'hyperexcitable' receptor ensuring effective postsynaptic depolarization when presynaptic activity is reduced [39]. Therefore, an increased expression of NR2D subunit in schizophrenic patients may be interpreted as a secondary regulation to glutamatergic hypoactivity in the right cerebellum, which was not seen in the left side. This supports results from the left cerebellum revealing no alterations in schizophrenic patients [1]. Additionally, we did not find alterations of NMDA receptor binding in our sample of schizophrenic patients.

In patients suffering from schizophrenia, decreased NMDA receptor function has been hypothesized to lead to glutamatergic dysfunction in cortical projections [44]. The

Human

\begin{tabular}{|c|c|c|c|}
\hline chr8: & \\
NRG1 & NRG1 \\
NRG1 \\
NRG1 \\
NRG1 \\
NRG1 \\
NRG1 \\
NRG1 \\
NRG1
\end{tabular}

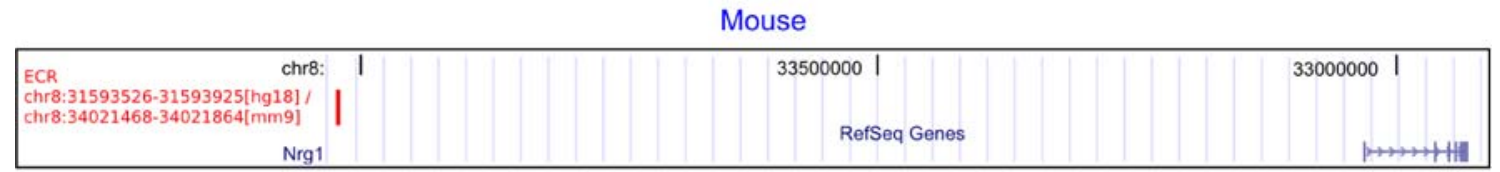

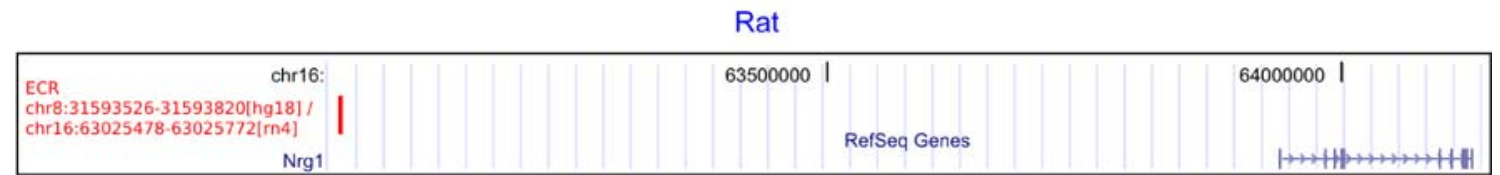

Fig. 3 Human: localization of rs35753505 (SNP8NRG221533) relative to NRG1 transcripts (RefSeq). Mouse and rat: localization of the evolutionary conserved region (ECR) in red, in which the human SNP is located. The orientation of the mouse sequence is reversed since mouse $\mathrm{Nrgl}$ is coded by the opposite strand. ECR coordinates refer to the annotations of the ECR browser (hg18, February 2007) and of the UCSC Genome Browser for $\mathrm{mm} 9$ and $\mathrm{rn} 4$ assemblies, respectively 


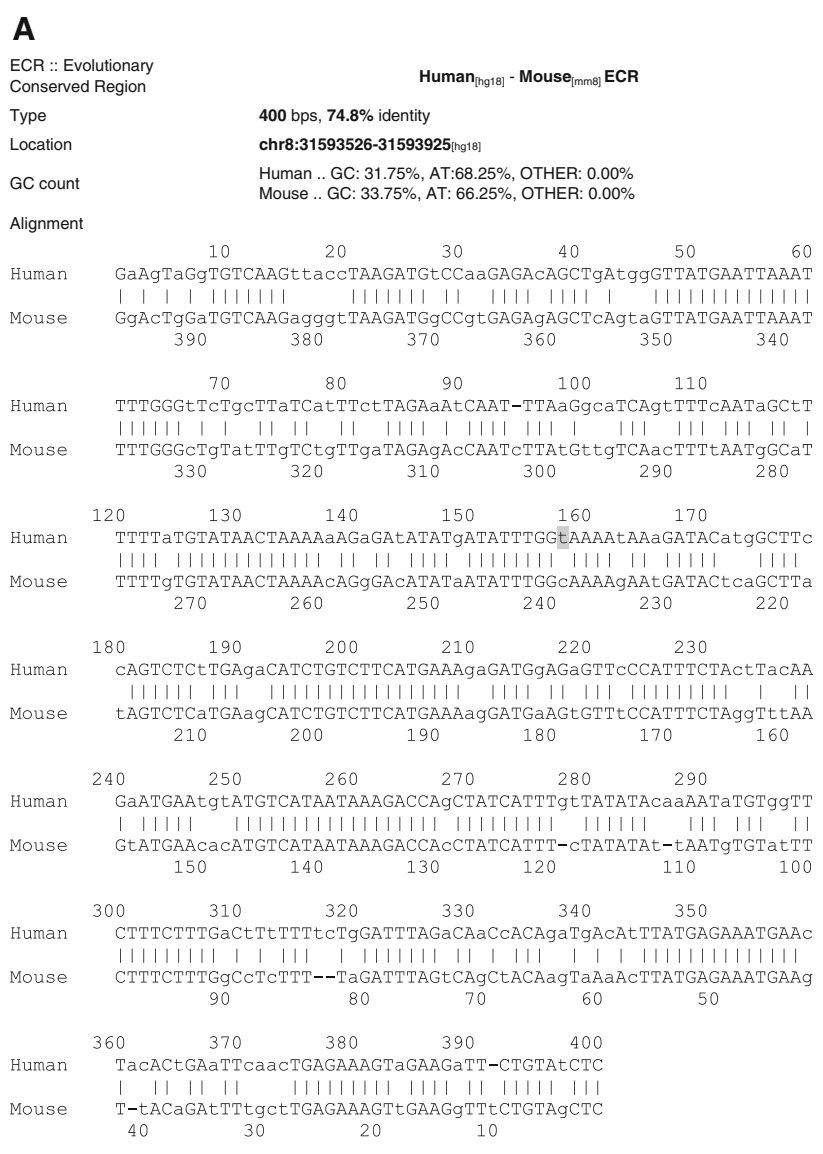

B

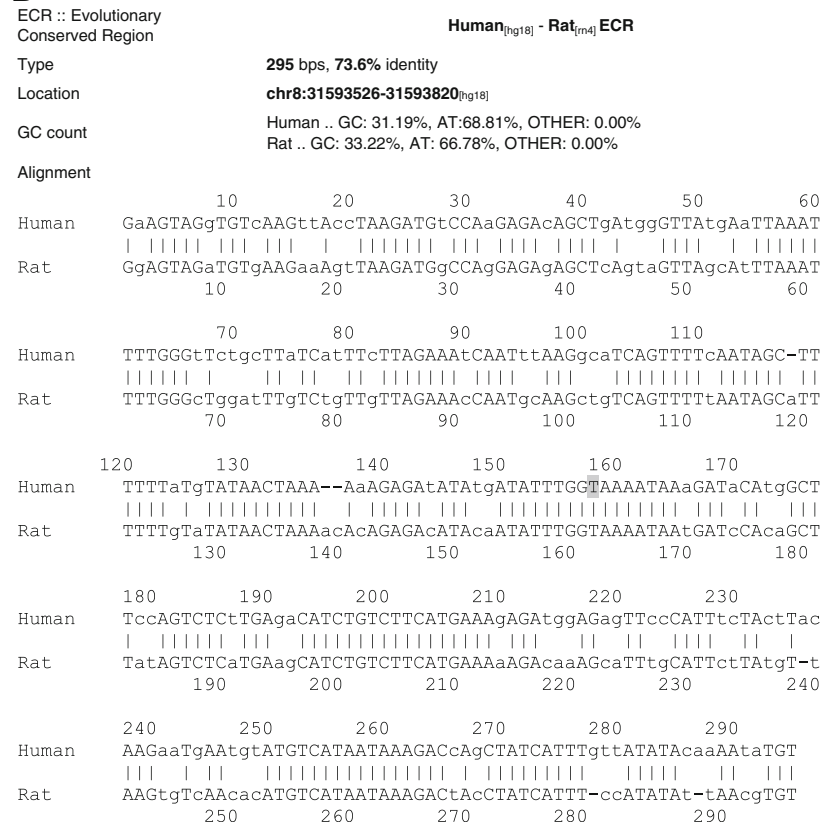

Fig. 4 ECR browser 'Grab ECR' alignment from both species in pairwise comparisons (ECR browser, February 2007). a human/ mouse ECR, b human/rat ECR. Position of rs35753505 (SNP8NRG221533) is highlighted in grey. Additionally, the length, percentage identity, $\mathrm{G}+\mathrm{C}$ content and genomic coordinates of the ECR are given schizophrenic phenotype may then appear in young adulthood, when the brain becomes vulnerable to the pre-existing NMDA receptor hypofunction [19]. Genetic factors can influence the brain and different risk genes associated with schizophrenia are known to influence the glutamatergic NMDA receptor such as dysbindin, metabotropic glutamate receptor 3, prolindehydrogenase, G72, DAAO and NRG1 leading to an NMDA receptor hypofunction. Several studies have identified the NRGl gene as a candidate gene for schizophrenia [23, 33]. The originally reported core at-risk haplotype consists of two microsatellite markers and five single nucleotide ploymorphosms (SNPs) [58]. The core at-risk haplotype of seven markers can be identified using only three markers (the SNP SNP8NRG221533 and the two microsatellites 478B14-848 and 420M9-1395) [59]. As typing of the microsatellite markers results in very small sample groups for each allelic type, we focused on genotyping of the frequent SNP rs35753505 (SNP8NRG221533), which showed the best uncorrected single marker association in the study of Stefansson et al. [58] and is a commonly reported marker in schizophrenia association studies [for metaanalysis/review see: 34, 40, 53, 59]. Positive association findings with rs35753505 (SNP8NRG221533) and schizophrenia or schizophreniarelated phenotypes were reported: schizophrenia $[57,58$, 62]; NRG1 SNP8NRG221533 and IL-1B -511 genotypes in combination [20, 22]; nondeficit schizophrenia [5]; response to conventional antipsychotics [31]; fractional anisotropy, which reflects structural integrity of white matter [61]; P300 latency [9]; activation in brain regions important for schizophrenia [32].

The localization of rs35753505 (SNP8NRG221533) in an ECR suggests selection and possible functional importance of the DNA sequence which harbours this polymorphism. Among distantly related mammals, only a few percent of the noncoding sequence is conserved, and within these regions occurrence of functional variation has been suggested [15].

The code that underlies vertebrate gene regulation is still not well understood [49]. Despite this uncertainty, evolutionary sequence conservation is considered a reliable indicator of biological activity [49], and several noncoding ECRs were validated as enhancers [13, 38, 41, 49, 50]. Noncoding, intergenic or intronic, sequence identity greater than or equal to $70 \%$ over at least 100 base pairs in orthologous human-mouse alignments is a commonly used threshold to detect ECRs [13-15, 37, 38, 41, 45, 49]. The localization of the ECR in which rs35753505 (SNP8NRG221533) is located, together with the position upstream of the transcriptional start sites of all NRGI transcript isoforms (RefSeq), as displayed in Fig. 3, suggests that this chromosomal region may be of importance for the transcriptional regulation of $N R G 1$. 
The neuregulin- $\beta$ isoform of NRGl is known to induce gene expression of the NR2C subunit in cerebellar neurons [47], but is not the one in closest proximity to rs 35753505 (SNP8NRG221533), rather suggesting an influence of the polymorphism on the GGF2-isoform of NRG1. It was proposed that neuregulin 1-coded signal molecules exert influence on NMDA receptor subunit NR2C expression in a transsynaptic mode: presynaptically located neuregulin 1-coded proteins are signal-dependent proteolytically cleaved, the extracellular fragment released into the synaptic cleft, where it binds to postsynaptic ErB receptors. Activated ErB receptors then translocate to the nucleus and influence postsynaptic NMDA receptor gene expression, thus mediating the information from neuregulin 1-coded proteins on the subunit composition of NMDA receptors in the postsynaptic cell $[46,56]$. Yet, the complete mechanisms underlying the contribution of NRG1 risk genotypes to disease pathophysiology remain elusive.

To the best of our knowledge, the impact of genetic variation in NRG1 on the expression of NMDA receptor subunits has not been studied so far. Our exploratory study suggests that NRG1 may be involved in the regulation of the expression of the NR2C subunit. In brain tissue with genotypes containing at least one $\mathrm{C}$ allele of rs35753505 (SNP8NRG221533), NR2C expression was decreased. This finding was confined to the molecular layer of the right cerebellum. Decreased expression may then lead to an NMDA receptor hypofunction, since $\mathrm{NR} 2 \mathrm{C}$, as a major NMDA receptor subunit of the cerebellum, exhibits less marked voltage-sensitive magnesium blockade and prolonged decay rate of glutamate-induced ion currents [39]. A deficiency in this subunit may cause decreased receptor activation during glutamatergic stimulation and, as a consequence, diminished synaptic sprouting [36]. However, we would like to point out that the results of our genetic study should be viewed with caution, given that we pursued an exploratory strategy, which did not include an adjustment for multiple testing. Moreover, it is based on a limited sample size. Thus, a replication of our finding in a larger sample is warranted in order to evaluate the role of NRG1 polymorphism in the expression of NR2C subunits.

Beside its motor function, the cerebellum is activated during attention [3]. Moreover, the cerebellum is lateralized and, as shown in an fMRI study, the right cerebellum and the left prefrontal cortex are both activated during a silent fluency task in right-handed healthy subjects [24]. It has been proposed that a cortical-thalamic-cerebellar-cortical circuit may be disturbed in the pathophysiology of schizophrenia and may lead to a misconnection syndrome with consecutive impairments of cognitive processes [4]. Cognitive functioning depends on the plasticity mediated, in part, by NMDA receptors [11]. Consistent with this, ${ }^{1} \mathrm{H}-\mathrm{MRS}$ as well as gene expression studies in schizophrenia reveal a hypoglutamatergic deficit in the left prefrontal cortex $[1,6]$, thalamus $[25,55]$ and cerebellum [16]. In the granule cell layer of the cerebellar cortex, the glutamatergic synaptic protein complexin II was reduced at the mRNA and protein level in schizophrenia patients compared to healthy controls [16]. However, these authors did not distinguish between the left and right hemisphere. Inline with this study, our results suggest a hypoglutamatergic deficit in schizophrenia. In this respect, our study is the first to describe lateralized alterations on the molecular level.

Since all patients involved in this study had been treated with antipsychotics over decades, medication effects may have influenced our results. In both sides of the cerebellum, expression of the NR2C subunit correlated with the duration of medication and our animal study revealed increased expression in clozapine-treated rats compared to haloperidol treatment. Therefore, clozapine may be superior to haloperidol in restoring a deficit of NR2C expression in the right cerebellum. However, it must also be noted that the study showed no differences between saline-treated rats and treatment groups. Additionally, duration of medication seemed to influence expression of the NR2D subunit only in the left cerebellum where we did not detect differences between patients and normal comparison subjects. In contrast, duration of illness may have an influence on NR2C and NR2D expression, but again, on the right side, where we only found diagnostic effects for NR2D expression, and observed no significant correlations with duration of illness.

A limiting factor of our study is its small sample and the ensuing fact that results will become insignificant after corrections for multiple testing. Thus, the results of this explorative study should be verified in a larger sample. Since many findings in post-mortem tissue are not specific for schizophrenia, psychiatric patients with other diagnoses such as bipolar disorder should be investigated to show disease-specific effects on NMDA receptor expression. Moreover, since we did not investigate protein levels of NMDA receptor subunits, it is not clear, if changes in the level of the mRNA transcript also reflect changes in protein levels, again limiting our conclusions. A complex interaction of genes, such as NRGl (or other promising vulnerability genes) and environmental factors may contribute to the aetiology of schizophrenia. Although the results of our study point to alterations in gene expression of NMDA receptor subunits, further studies are warranted to elucidate the precise nature of the glutamatergic hypofunction in schizophrenia.

Acknowledgments This study was supported by the European Commission under the Sixth Framework Programme (BrainNet Europe II, LSHM-CT-2004-503039). The paper reflects only the authors' 
views and the Community is not liable for any use that may be made of it. The authors would like to thank Udo Rueb for Braak staging and Mrs. Waltraud VanSyckel for English text revision.

Conflict of interest statement All authors (Andrea Schmitt, Jiri Koschel, Mathias Zink, Manfred Bauer, Clemens Sommer, Josef Frank, Jens Treutlein, Thomas Schulze, Thomas Schneider-Axmann, Eleni Parlapani, Marcella Rietschel, Peter Falkai, Fritz A Henn) reported no biomedical financial interests or potential conflicts of interest.

Open Access This article is distributed under the terms of the Creative Commons Attribution Noncommercial License which permits any noncommercial use, distribution, and reproduction in any medium, provided the original author(s) and source are credited.

\section{References}

1. Akbarian S, Sucher NJ, Bradley D, Tafazzoli A, Trinh D, Hetrick WP, Potkin SG, Sandman CA, Bunney WE Jr, Jones EG (1996) Selective alterations in gene expression for NMDA receptor subunits in prefrontal cortex of schizophrenics. J Neurosci 16:19-30

2. Akshoomoff NA, Courchesne E, Townsend J (1997) Attention coordination and anticipatory control. Int Rev Neurobiol 41:575598

3. Allen G, Buxton RB, Wong EC, Courchesne E (1997) Attentional activation of the cerebellum independent of motor involvement. Science 275:1940-1943

4. Andreasen NC, Nopoulos P, O'Leary DS, Miller DD, Wassink T, Flaum M (1999) Defining the phenotype of schizophrenia: cognitive dysmetria and its neural mechanisms. Biol Psychiatry 46:908-920

5. Bakker SC, Hoogendoorn ML, Selten JP, Verduijn W, Pearson PL, Sinke RJ, Kahn RS (2004) Neuregulin 1: genetic support for schizophrenia subtypes. Mol Psychiatry 9:1061-1063

6. Bartha R, Williamson PC, Drost DJ, Malla A, Carr TJ, Cortese L, Canaran G, Rylett RJ, Neufeld RWJ (1997) Measurement of glutamate and glutamine in the medial prefrontal cortex of nevertreated schizophrenic patients and healthy controls by proton magnetic resonance spectroscopy. Arch Gen Psychiatry 54:959965

7. Braak H, Alafuzoff I, Arzberger T, Kretzschmar H, Del Tredici K (2006) Staging of Alzheimer disease-associated neurofibrillary pathology using paraffin sections and immunocytochemistry. Acta Neuropathol 112:389-404

8. Braak H, Braak E (1991) Neuropathological stageing of Alzheimer-related changes. Acta Neuropathol 82:239-259

9. Bramon E, Dempster E, Frangou S, Shaikh M, Walshe M, Filbey FM, McDonald C, Sham P, Collier DA, Murray R (2008) Neuregulin-1 and the P300 waveform-a preliminary association study using a psychosis endophenotype. Schizophr Res 103:178185

10. Cull-Candy SG, Brickley SG, Misra C, Feldmeyer D, Momiyama A, Farrant M (1998) NMDA receptor diversity in the cerebellum: identification of subunits contributing to functional receptors. Neuropharmacology 37:1369-1380

11. Daw NW, Stein PS, Fox K (1993) The role of NMDA receptors in information processing. Annu Rev Neurosci 16:207-222

12. Deicken RF, Feiwell R, Schuff N, Soher B (2001) Evidence for altered cerebellar vermis neuronal integrity in schizophrenia. Psychiatry Res 107:125-134

13. Dermitzakis ET, Reymond A, Antonarakis SE (2005) Conserved non-genic sequences-an unexpected feature of mammalian genomes. Nat Rev Genet 6:151-157
14. DeSilva U, Elnitski L, Idol JR, Doyle JL, Gan W, Thomas JW, Schwartz S, Dietrich NL, Beckstrom-Sternberg SM, McDowell JC et al (2002) Generation and comparative analysis of approximately $3.3 \mathrm{Mb}$ of mouse genomic sequence orthologous to the region of human chromosome 7q11.23 implicated in Williams syndrome. Genome Res 12:3-15

15. Drake JA, Bird C, Nemesh J, Thomas DJ, Newton-Cheh C, Reymond A, Excoffier L, Attar H, Antonarakis SE, Dermitzakis ET, Hirschhorn JN (2006) Conserved noncoding sequences are selectively constrained and not mutation cold spots. Nat Genet 38:223-227

16. Eastwood SL, Cotter D, Harrison PJ (2001) Cerebellar synaptic protein expression in schizophrenia. Neuroscience 105:219-229

17. Ende G, Hubrich P, Walter S, Weber-Fahr W, Kämmerer N, Braus DF, Henn FA (2005) Further evidence for altered cerebellar neuronal integrity in schizophrenia. Am J Psychiatry 162:790-792

18. Farber NB, Newcomer JW, Olney JW (1999) Glycine agonists: what can they teach us about schizophrenia? Arch Gen Psychiatry 56:13-17

19. Farber NB, Wozniak DF, Price MT, Labruyere J, Huss J, St Peter H, Olney JW (1995) Age-specific neurotoxicity in the rat associated with NMDA receptor blockade: potential relevance to schizophrenia? Biol Psychiatry 38:788-796

20. Georgieva L, Dimitrova A, Ivanov D, Nikolov I, Williams NM, Grozeva D, Zaharieva I, Toncheva D, Owen MJ, Kirov G, O’Donovan MC (2008) Support for neuregulin 1 as a susceptibility gene for bipolar disorder and schizophrenia. Biol Psychiatry $64: 419-427$

21. Ghez C, Fahn S (1985) The cerebellum. In: Kandel ER, Schwartz $\mathrm{JH}$ (eds) Principals of neural science. Elsevier, New York, pp 502-522

22. Hänninen K, Katila H, Saarela M, Rontu R, Mattila KM, Fan M, Hurme M, Lehtimäki T (2008) Interleukin-1 beta gene polymorphism and its interactions with neuregulin-1 gene polymorphism are associated with schizophrenia. Eur Arch Psychiatry Clin Neurosci 258:10-15

23. Harrison PJ, Weinberger DR (2005) Schizophrenia genes, gene expression, and neuropathology: on the matter of their convergence. Mol Psychiatry 10:40-68

24. Hubrich-Ungureanu $\mathrm{P}$, Kaemmerer N, Henn FA, Braus DF (2002) Lateralized organization of the cerebellum in a silent verbal fluency task: a functional magnetic resonance imaging study in healthy volunteers. Neurosci Lett 319:91-94

25. Ibrahim HM, Hogg AJ Jr, Healy DJ, Haroutunian V, Davis KL, Meador-Woodruff JH (2000) Ionotropic glutamate receptor binding and subunit mRNA expression in thalamic nuclei in schizophrenia. Am J Psychiatry 157:1811-1823

26. Ichimiya T, Okubo Y, Suhara T, Sudo Y (2001) Reduced volume of the cerebellar vermis in neuroleptic-naive schizophrenia. Biol Psychiatry 49:20-27

27. Ishii T, Moriyoshi K, Sugihara H, Sakurada K, Kadotani H, Yokoi M, Akazawa C, Shigemoto R, Mizuno N, Masu M et al (1993) Molecular characterization of the family of the $N$-methyl-D-aspartate receptor subunits. J Biol Chem 268:28362843

28. Jahn T, Mussgay L (1989) Die statistische Kontrolle möglicher Medikamenteneinflüsse in experimentalpsychologischen Schizophreniestudien: ein Vorschlag zur Berechnung von Chlorpromazinäquivalenten. Z Klin Psychol 18:257-267

29. Javitt DC, Zukin SR (1991) Recent advances in the phencyclidine model of schizophrenia. Am J Psychiatry 148:1301-1308

30. Jentsch JD, Roth RH (1999) The neuropsychopharmacology of phencyclidine: from NMDA receptor hypofunction to the dopamine hypothesis of schizophrenia. Neuropsychopharmacology 20:201-225 
31. Kampman O, Anttila S, Illi A, Saarela M, Rontu R, Mattila KM, Leinonen E, Lehtimäki T (2004) Neuregulin genotype and medication response in Finnish patients with schizophrenia. NeuroReport 15:2517-2520

32. Kircher T, Thienel R, Wagner M, Reske M, Habel U, Kellermann T, Frommann I, Schwab S, Wölwer W, von Wilmsdorf $M$ et al (2009) Neuregulin 1 ICE-single nucleotide polymorphism in first episode schizophrenia correlates with cerebral activation in fronto-temporal areas. Eur Arch Psychiatry Clin Neurosci 259:72-79

33. Law AJ, Lipska BK, Weickert CS, Hyde TM, Straub RE, Hashimoto R, Harrison PJ, Kleinman JE, Weinberger DR (2006) Neuregulin 1 transcripts are differentially expressed in schizophrenia and regulated by $5^{\prime}$ SNPs associated with the disease. Proc Natl Acad Sci USA 103:6747-6752

34. Li D, Collier DA, He L (2006) Meta-analysis shows strong positive association of the neuregulin 1 (NRG1) gene with schizophrenia. Hum Mol Genet 15:1995-2002

35. Lillifors $H$ (1967) On the Kolmogorov-Smirnov test for normality with mean and variance unknown. J Am Stat Assoc 62:399

36. Lipton SA, Kater SB (1989) Neurotransmitter regulation of neuronal outgrowth, plasticity and survival. Trends Neurosci $12: 265-270$

37. Liu J, Francke U (2006) Identification of cis-regulatory elements for MECP2 expression. Hum Mol Genet 15:1769-1782

38. Loots GG, Locksley RM, Blankespoor CM, Wang ZE, Miller W, Rubin EM, Frazer KA (2000) Identification of a coordinate regulator of interleukins 4,13 , and 5 by cross-species sequence comparisons. Science 288:136-140

39. Monyer H, Burnashev N, Laurie DJ, Sakmann B, Seeburg PH (1994) Developmental and regional expression in the rat brain and functional properties of four NMDA receptors. Neuron 12:529-540

40. Munafo MR, Thiselton DL, Clark TG, Flint J (2006) Association of the NRG1 gene and schizophrenia: a meta-analysis. Mol Psychiatry 11:539-546

41. Nobrega MA, Ovcharenko I, Afzal V, Rubin EM (2003) Scanning human gene deserts for long-range enhancers. Science 302:413

42. Norusis M (2000) SPSS ${ }^{\circledR} 10.0$ Guide to data analysis. Prentice Hall, Upper Saddle River, New Jersey

43. Okugawa G, Sedvall G, Nordström M, Andreasen N, Pierson R, Magnotta V, Agartz I (2002) Selective reduction of the posterior superior vermis in men with chronic schizophrenia. Schizophr Res 55:61-67

44. Olney JW, Farber NB (1995) Glutamate receptor dysfunction and schizophrenia. Arch Gen Psychiatry 52:998-1007

45. Ovcharenko I, Nobrega MA, Loots GG, Stubbs L (2004) ECR Browser: a tool for visualizing and accessing data from comparisons of multiple vertebrate genomes. Nucleic Acids Res 32:W280-W286

46. Ozaki M, Tohyama K, Kishida H, Buonanno A, Yano R, Hashikawa $\mathrm{T}$ (2000) Roles of neuregulin in synaptogenesis between mossy fibers and cerebellar granule cells. J Neurosci Res 59:612623

47. Ozaki M, Sasner M, Yano R, Lu HS, Buonanno A (1997) Neuregulin-beta induces expression of an NMDA-receptor subunit. Nature 390:691-694

48. Paxinos G, Watson C (1986) The rat brain in sterotaxic coordinates. Academic Press, Marrickville
49. Pennacchio LA, Loots GG, Nobrega MA, Ovcharenko I (2007) Predicting tissue-specific enhancers in the human genome. Genome Res 17:201-211

50. Pennacchio LA, Ahituv N, Moses AM, Prabhakar S, Nobrega MA, Shoukry M, Minovitsky S, Dubchak I, Holt A, Lewis KD et al (2006) In vivo enhancer analysis of human conserved noncoding sequences. Nature 444:499-502

51. Rees G, Frackowiak R, Frith C (1997) Two modulatory effects of attention that mediate object categorization in human cortex. Science 275:835-838

52. Scherzer CR, Landwehrmeyer GB, Kerner JA, Standaert DG, Hollingsworth ZR, Daggett LP, Velicelebi G, Penney JB Jr, Young AB (1997) Cellular distribution of NMDA glutamate receptor subunit mRNAs in the human cerebellum. Neurobiol Dis 4:35-46

53. Schmitt A, Parlapani E, Gruber O, Wobrock T, Falkai P (2008) Impact of neuregulin-1 on the pathophysiology of schizophrenia in human post-mortem studies. Eur Arch Psychiatry Clin Neurosci 258(Suppl 5):35-39

54. Schmitt A, Zink M, Müller B, May B, Herb A, Jatzko A, Braus DF, Henn FA (2003) Effects of long-term antipsychotic treatment on NMDA receptor binding and gene expression of subunits. Neurochem Res 28:235-241

55. Smith RE, Haroutunian V, Davis KL, Meador-Woodruff JH (2001) Expression of excitatory amino acid transporter transcripts in the thalamus of subjects with schizophrenia. Am J Psychiatry 158:1393-1399

56. Stefansson H, Steinthorsdottir V, Thorgeirsson TE, Gulcher JR, Stefansson K (2004) Neuregulin 1 and schizophrenia. Ann Med 36:62-71

57. Stefansson H, Sarginson J, Kong A, Yates P, Steinthorsdottir V, Gudfinnsson E, Gunnarsdottir S, Walker N, Petursson H, Crombie $\mathrm{C}$ et al (2003) Association of neuregulin 1 with schizophrenia confirmed in a Scottish population. Am J Hum Genet 72:83-87

58. Stefansson H, Sigurdsson E, Steinthorsdottir V, Bjornsdottir S, Sigmundsson T, Ghosh S, Brynjolfsson J, Gunnarsdottir S, Ivarsson O, Chou TT et al (2002) Neuregulin 1 and susceptibility to schizophrenia. Am J Hum Genet 71:877-892

59. Tosato S, Dazzan P, Collier D (2005) Association between the neuregulin 1 gene and schizophrenia: a systematic review. Schizophr Bull 31:613-617

60. Volz H, Gaser C, Sauer H (2000) Supporting evidence for the model of cognitive dysmetria in schizophrenia-a structural magnetic resonance imaging study using deformation-based morphometry. Schizophr Res 46:45-56

61. Winterer G, Konrad A, Vucurevic G, Musso F, Stoeter P, Dahmen N (2008) Association of $5^{\prime}$ end neuregulin-1 (NRG1) gene variation with subcortical medial frontal microstructure in humans. Neuroimage 40:712-718

62. Yang JZ, Si TM, Ruan Y, Ling YS, Han YH, Wang XL, Zhou M, Zhang HY, Kong QM, Liu C et al (2003) Association study of neuregulin 1 gene with schizophrenia. Mol Psychiatry 8:706-709

63. Zilles K, Qü MS, Köhling R, Speckmann EJ (1999) Ionotropic glutamate and GABA receptors in human epileptic neocortical tissue: quantitative in vitro receptor autoradiography. Neuroscience 94:1051-1061

64. Zink M, Schmitt A, May B, Müller B, Demirakca T, Braus DF, Henn FA (2004) Differential effects of long-term treatment with clozapine or haloperidol on GABAA receptor binding and GAD67 expression. Schizophr Res 66:151-157 